\title{
The South African Military and Peace Support Operations: Responding to the Challenges and Preparing for Engagement
}

\author{
DR T.G. NEETHLING \\ Centre for Military Studies, University of Stellenbosch
}

Suid-Afrika het in die afgelope tyd om meer as een rede toenemend by politiekdiplomatieke vredesinisiatiewe betrokke geraak. Op die militêre terrein is die SuidAfrikaanse Nasionale Weermag (SANW) eweneens besig met voorbereidings om op multilaterale grondslag aan toekomstige vredesondersteunde operasies deel te neem. Met die oog op sodanige deelname is die SANW tans besig om in samewerking met buitelandse weermagte aandag te skenk aan ' $n$ grondslag vir gesamentlike optrede. Selfs meer betekenisvol is Suid-Afrika se ontwikkelende politieke en diplomatieke status in Suider-Afrika en die koördinering van inisiatiewe om 'n gemeenskaplike veiligheidsbenadering op die sub-kontinent te bevorder. In dié opsig speel die land ' $n$ belangrike rol in pogings om ' $n$ nuwe veiligheids- en verdedigingsprofiel in Suider-Afrika te laat vorm aanneem.

In die lig van toenemende verwagtinge wat met betrekking tot vredesinisiatiewe aan Suid-Afrika gestel word, asook in die konteks van die uitdagings en risikos wat vredesondersteunde operasies inhou, spreek dit vanself dat enige toekomstige deelname daaraan met omsigtigheid oorweeg moet word. Verskeie politieke en operasionele oorwegings moet in dié verband in aanmerking geneem word. Wat dit betref, is die Departement van Verdediging skynbaar deeglik onder die indruk van die politie-ke en militêre dinamiek van vredesondersteunende operasies, asook die onervarend-heid van die SANW in dié opsig. Gevolglik is bepaalde parameters, riglyne en selfs voorwaardes vir deelname aan sodanige operasies uitgestippel. As sodanig is daar klaarblyklik ' $n$ besef dat die land op ' $n$ verantwoordelike wyse en langs die weg van ' $n$ bepaalde proses daarby betrokke behoort te raak.

\section{INTRODUCTION}

After many years of isolation in the international community, South Africa has been welcomed back into the community of nations and has joined or rejoined a host of regional 
and international organisations. Most significant among these are the United Nations (UN), the Organisation of African Unity (OAU) and the Southern African Development Community (SADC). The country has also entered into a number of international and regional bilateral or multilateral defence agreements. Moreover, as a fully-fledged member of the community of nations South Africa is now preparing to fulfill its responsibility to participate in international and regional peace support operations. ${ }^{1}$

In South Africa the possibility of a future peace support role for the South African National Defence Force (SANDF) was clearly endorsed at the highest political level by President Mandela himself. Defence-related policy statements repeatedly emphasised that South Africa's security policy was founded upon compliance with and adherence to international law, the Charter of the UN and the policy guidelines emanating from the UN Security Council, while also taking the policy of the OAU into account. To demonstrate its commitment to peace initiatives, the country contributed a substantial amount to the $\mathrm{UN}$ to provide financial assistance for international peacekeeping in Africa. At diplomatic level South Africa has edged closer to committing its forces to involvement in an international force after almost guaranteeing "safe corridors" for the return of Rwandan refugees in November 1996. ${ }^{2}$

Against this background, it is anticipated that, sooner or later the South African military will play a leading role in the security requirements of Southern Africa and even as far afield as Central Africa. The Department of Defence and other role-players consequently proceeded to anticipate policy and developments in relation to future peace support operations. Significant spadework has already been done in this regard, although some questions remain to be clarified.

This article will assess the anticipated future participation of the South African military in peace support operations in Southern Africa. More specifically, it intends to reflect on the motives for South African involvement, after which it will sketch the framework for the conducting of international peace missions and co-operative security in the sub-continent. In this context it will reflect on and discuss relevant policy and operational factors to be considered and conditions to be met before committing SANDF forces to peace initiatives.

\section{THE MOTIVES FOR SOUTH AFRICAN INVOLVEMENT}

There may be more than one reason for countries to become motivated to participate in peace support operations. One reason may be that peacekeeping is viewed by some as a

1 Peace support operations will be used as the generic or umbrella term encompassing all the types of possible mission support or peace operations on the part of the SANDF.

2 The South African Air Force's involvement in the peace missions in Mozambique in 1992, as well as Angola and Rwanda since 1994 was confined to the rendering of humanitarian aid and did not entail any troop-deployment. 
means of keeping armed forces gainfully occupied. Others may relate to international influence and obligations.

Until recently, some of the more traditional peacekeeping participants, such as Canada and the Scandinavian countries, equated participation in peacekeeping with "good international citizenship". However, current indications are that considerations of altruism are on the wane and stand to be replaced by national prestige and own interest - particularly since many newcomers were added to the number of peacekeeping nations since the late 1980's (Cilliers and Malan, 1996:342-343).

Speaking on behalf of the United Kingdom (UK), former Secretary of State for Defence, Mr. Malcolm Rifkind, outlined the (then) British perspective as follows:

"We need to consider the criteria against which the UK should judge whether or not to become involved in a peacekeeping or peacemaking mission. The first criterion must be the national interest... It is difficult to predict where conflicts may lead, and wider strategic and security interests, not always defence related, come into play" (Rifkind, 1993:2-3).

Other factors of consideration on the part of a country like the UK relate to its position and commitments as a permanent member of the UN Security Council (Rifkind, 1993:2). In the case of the United States (US), US Presidential Decision Directive 25 clearly declares the following:

"When deciding whether to support a particular UN peace operation, the United States will insist that fundamental questions be asked before new obligations are undertaken. These include an assessment of the threat to international peace and security, a determination that the peace operation serves US interests..." (as quoted by Ramsbotham, 1995:5).

As far as the South African position is concerned, President Mandela stated in a speech to the UN that peace, security and stability and the prevention, management and resolution of conflict cannot be regarded in military terms alone. He went on to say that, "...hundreds of millions of ...politically empowered masses are caught in the deadly trap of poverty, unable to live life in its fullness. Out of this are born social conflicts which produce insecurity and instability, civil wars and other wars that claim many lives and millions of desperate refugees..." (as quoted by Pahad, 1995:154).

Accordingly, Deputy Minister of Foreign Affairs, Mr. Aziz Pahad, stated that any meaningful effort to deal with conflict prevention and resolution must, among others, consider the following issues:

- The promotion of human rights, democracy and good governance.

- The promotion of the political, economic and social well-being of the poor, based on the creation of "people centered societies".

- The protection of the environment.

- The prohibition and control of arms proliferation.

- The control of arms smuggling, drug trafficking, refugees, mass migration, disease, 
drought and other natural disasters.

- The status of women (Pahad, 1995:154-155).

For Cilliers and Malan (1996:342) the South African position relates to a debt that South Africa feels it owes to the international community for helping to bring democracy to the country. It follows that participation in peacekeeping is therefore a way of repaying the debt that the new rulers feel they owe to the international community. Morality aside, South Africa is also a leader on the African continent and it is clearly in its economic interest to do all within its power to be instrumental in stabilising the region.

Gutteridge (1997:6-7) remarks that the South African lobby favouring international military involvement is strongly concerned with political prestige and professional military pride - in other words an assertion of South Africa's willingness and professional capability to accept leadership responsibilities in the global hierarchy of states. This is linked to a conviction held in military circles that the SANDF has a duty as well as the ability to set an example in Africa which could assist the African continent to find a way out of the current widespread disorder. The South African position should, however, also be assessed in the context of expectations of the European Union that their perceived responsibilities in Africa can be shifted to South African shoulders, together with corresponding pressures for South Africa to take the lead in conflict prevention and to undertake military security responsibilities.

Against this background it would appear that factors related to morality, altruism, national interest as well as international interest in African affairs will largely determine South Africa's short and medium term goals in relation to peace missions. South Africa is, however, seemingly aware of the dangers of acquiring an excessive role in the Southern African region or the continent at large and is therefore concentrating on planning for participation in the conducting of international peace support operations on a multilateral basis through the UN and on the sub-continent through the OAU and the SADC.

\section{THE BROAD INSTITUTIONAL FRAMEWORK}

Success in any peace mission depends on a broad political process. Peace support operations never comprise only military exercises. In fact, military operations play a distinctly supportive role and may even produce few obvious results as regards the outcome.

To ensure success, peace support operations are thus critically dependent upon the international authority that underpins operations and the political will of participating member states. This kind of authority is necessary to assist in reducing political pressure on the countries responsible, avoids international isolation of the participating countries if the operation "goes wrong" and prevents overextending the capabilities of any country's armed forces (Williams, 1995:91-92). Such political apparatus and institutional framework entails a complex amalgam of political, diplomatic, military and economic measures at both a domestic and broader level. 


\section{Participation in international peace support operations}

The Department of Defence has clearly indicated that South Africa, as a fully-fledged member of the international community, will fulfill its responsibility to participate in international peace support operations. In order to prepare for peace missions, the SANDF is investigating the development of appropriate doctrines, operational procedures and training programmes in co-operation with foreign partners. South Africa has therefore entered into a number of international defence agreements. These generally entail reciprocal obligations and an undertaking to engage in some form of co-operation.

South Africa's destiny, however, lies within Southern Africa. For political, strategic and geographical reasons, the Government regards security and defence co-operation in Southern Africa as a priority and in terms thereof, it is especially committed to the development of a common security approach in the region (Department of Defence, 1996:22).

\section{Conflict prevention and co-operation in Africa and Southern Africa}

Significant spadework has been done to create an institutional framework for peace support operations in Africa and Southern Africa in particular. Suffice it to say that such a framework would be provided in an overarching capacity by the OAU and its Mechanism for Conflict Prevention, Management and Resolution. At the regional level the idea of an all-African Crisis Response Force, staffed and commanded almost exclusively by Africans, is increasingly being favoured as part of a broader series of political and diplomatic initiatives on the continent (Williams, 1997:1). At the subregional level, the SADC and its relevant structures, the Organ for Politics, Defence and Security and the Inter-State Defence and Security Committee (ISDSC) will provide the possible future framework for co-operation and assistance for peace initiatives and cooperative security in Southern Africa. This partnership will include the eleven contiguous member states of the SADC, as well as Mauritius.

The ISDSC has three sub-commitees, namely for defence, public security and state security. The main functions of the defence sub-committee are as follows:

- To review and share experiences on the military-security situation in member states.

- To explore areas for multi-lateral defence co-operation and the practical implementation thereof.

- To exchange views and propose mechanisms for the prevention, management and resolution of conflict in Africa in general and in Southern Africa in particular (Defence Review Drafting Team, 1996:29).

The model discussed here should be perceived in the context of the realisation that African states and organisations will have to accept an increasing burden of responsibility for conflict prevention and resolution on the continent, and that this could best be created oy means of co-operation at subregional level (Cilliers and Malan, 1996:339). The idea is 
also consistent with calls by African leaders such as President Mandela for "African solutions for African problems" (Shaw, 1997:6). As far as the manifestation of regional defence co-operation is concerned, it relates to an approach of security being viewed as a holistic phenomenon managed by a "common security regime" within the Southern African region (Da Costa, 1995:27-29).

The concept of common security as a policy framework would have many advantages. It would facilitate the sharing of information and resources; the early warning of potential crises; joint problem-solving; implementing confidence- and security-building measures to provide for greater transparency in regional military matters; negotiating security arrangements; and resolving inter-state conflict through peaceful means (Department of Defence, 1996:27).

If regional organisations are primarily responsible for dealing with their own security problems, it does not imply that this should subvert from UN guidance and control. Nhara (1995:100) states that regional organisations and arrangements on the one hand, and the UN system on the other, should endeavour to share the responsibility of maintaining peace. However, the UN, with its cumulative experience, should, remain the pre-eminent international authority responsible for dealing with international peace and security, as well as with internal crises that threaten regional stability, particularly in Africa. In view of this Arnold (1997:33) makes mention of an approach that assigns peacekeeping responsibilities to regional or other organisations.

Arnold (1997:33) also points out that such an approach would, in fact, be in accordance with current UN policy, as was the case with the involvement of the Economic Community of African States Monitoring Group (ECOMOG) in Liberia. Cilliers and Malan (1996:340) likewise indicate that the UN has come to share responsibilities for peace support operations with regional organisations, for example in Georgia with the Russian Federation, and the North Atlantic Treaty Organisation (NATO) in the former Yugoslavia.

Pursuant to its leadership role in Southern Africa, South Africa and its counterparts in the ISDSC initiated discussions on certain political and military issues pertaining to the conduct of future peace support operations in 1995. In addition, the armed forces of eight Southern African countries (including a contingent of the SANDF) participated in Exercise Blue Hungwe, a two-week, multinational peace support exercise held early in 1997 in Zimbabwe, assisted and facilitated by British military experts. With this exercise the subregion came closer to sharing peace support responsibilities (Shaw, 1997:6).

\section{The decision-making framework}

As far as the South African decision-making framework for undertaking peace support operations is concerned, it should be briefly noted that, when South Africa is requested to participate in a peace support operation, the following will apply:

- Any request for participation will be channeled through the Department of Foreign 
Affairs. That Department will liaise closely with the National Intelligence Coordinating Committee and the Department of Defence.

- Any additional agreements on matters relating to the determination of the mission and objectives of the operation will be negotiated by the Department of Foreign Affairs in consultation with the SANDF.

- The Departments of Foreign Affairs and Defence will advise Cabinet on the matters referred to above. Cabinet is responsible for final decisions and, in terms of the Constitution, the deployment of the SANDF requires the authorisation of the President (Defence Review Team, 1997:33).

- The Department of Foreign Affairs, through the Department of Finance, has to finance peace support operations in cases of SANDF participation (Kritzinger, 1995:56;59).

\section{POLICY CONSIDERATIONS FOR SOUTH AFRICAN ENGAGEMENT}

Given South Africa's relative strength in Southern Africa, the country can clearly be regarded as a leader. Inevitable concomitant responsibilities flow from its position of economic and military strength. As the South African government is expected to play a leading role on the African continent, it has to carefully consider any commitment to participation in peace support operations. There are a number of questions which are bound to be raised, of which the most significant of these are:

- In what circumstances should South Africa risk participation in such operations?

- In what ways should the South African military contribute to peacekeeping?

- What is financially viable in participation in peace support operations?

Any decision to deploy troops will have to justify the risks involved while the Department of Defence will have to be satisfied that certain conditions are met.

\section{The question of mandates and parameters of engagement}

A survey of the UN's involvement in the former Yugoslavia, Cambodia and Somalia clearly suggests sharp differences in the nature and circumstances of the operations undertaken - a mixture of international and civil war involving radicalised ethnic groups in the former Yugoslavia, the implementation of a comprehensive political settlement in Cambodia and the collapse of governmental authority in Somalia. The experience of the UN forces in each of these theaters highlights a critical issue concerning the contemporary challenge of peacekeeping in internal conflicts, namely the problem of formulating mandates whose humanitarian and political objectives are effectively understood and reinforced by the presence of peacekeeping forces (Berdal, 1993:27).

In Somalia, for example, confusion was experienced even at the political level in the US over the exact parameters of the UN mission. Although originally designated as a 
peacekeeping mission, the operation in Somalia swiftly evolved into a combat operation. This appears to have caused confusion and a lack of understanding between the UN and the participating member states, resulting in the US decision to withdraw from Somalia (Roos, 1993:15).

The involvement of the US-led coalition forces in the northern part of Iraq in 1991 has clearly demonstrated that peacekeeping forces could find themselves quickly involved in extremely dynamic, fluid situations. At first the forces were involved in a constant offensive maneuver to evict the Iraqis from an expanding security zone. After a month of constant movement the operations assumed the more familiar shape of static peacekeeping (Abizaid, 1993:14).

Williams (1995:90-91) accordingly states that peacekeeping is in the midst of a practical and paradigmatic transition. Traditional peacekeeping is increasingly being challenged by peace enforcement operations where the use of force to prevent conflict is applied. In addition, many analysts maintain that no effective mechanisms or appropriate doctrine have yet been devised for responding to what is regarded as a "grey zone" in peacekeeping, namely the slippery area between peacekeeping and peace enforcement.

A lack of clarity on this issue can prove to be very dangerous with potentially disastrous consequences. In any peace operation, it is imperative to determine what actions are appropriate for forces to undertake. Without agreeing on what is exactly meant by "peacekeeping" and "peace enforcement", the forces engaged in such missions would end up attaching their own national or operational perspectives to each operation or situation (Roos, 1993:14).

In the context of the above Maloney (1996:12) remarks that changes in global power alignments necessitate a corresponding change in the application of military force. This has caused a fierce debate in military circles and even in the US, military specialists have in recent times been occupied with efforts to produce a codified basis for the conducting of peace support operations involving US forces.

As a result a Joint Task Force Commander's Handbook for Peace Support Operations have been published, covering all aspects in relation to US participation in peace initiatives. As such it provides clarity on matters relating to the scope of US peace missions; the question of mandates; joint task organisation and legal responsibilities (Joint Warfighting Center, 1995:i- iii).

In the case of Canada, which has been extensively involved in international peace support operations since 1948, the Canadian peacekeeping doctrine has until the early 1990 's been relatively ad hoc. After sustained operations in the Former Republic of Yugoslavia since 1991, and after operations in Somalia, the Canadian army has produced a comprehensive doctrinal manual, Operations Land and Tactical Air: Peacekeeping Operations.

The Canadian Peacekeeping doctrine derives from problems experienced in past peace missions and from long-standing Canadian policy that has constantly emphasised domes- 
tic national unity, domestic policy liberty, the rule of law in international affairs and the acceptance of international responsibilities in keeping with the Canadian role in international affairs (Maloney, 1996:12). It furthermore deals with various aspects in relation to:

- responding to UN requests for participation in international peacekeeping;

- historical limitations inherent to the UN system of peacekeeping;

- practical participation in UN and NATO peace forces; and

- taking part in peacekeeping operations as a generic term for peace enforcement, peacekeeping forces, observer missions and humanitarian assistance (Maloney, 1996:15-16).

The Nordic countries have likewise produced a manual, Nordic UN Stand-by Forces, which has been formally confirmed by the Danish, Finnish, Norwegian and Swedish Ministers of Defence in 1993. One of the purposes of this document is to present basic facts and information concerning Nordic experiences from UN operations. It is also an aide memoire dealing with all matters in respect of Nordic UN co-operation and the initiation of a UN operation; i.e. considerations and factors in connection with a $\mathrm{UN}$ peacekeeping operation; modalities of operations; and the establishment of a peacekeeping operation. Different types of peace support operations are also outlined, namely preventive diplomacy; peacemaking; peacekeeping and peace-building (NORDSAMFN, 1993:2-7).

Against this background Nöffke (1995:15) remarks that the US and the major powers normally do not intervene militarily in regional conflicts unless internal political advantages could be attained, their security and economic interests are threatened and/or an acceptable level of safety of their intervention forces can be assured.

\section{The establishment of criteria for the commitment of South African forces}

From the above it is clear that, before the SANDF can become involved in peace support operations or providing aid to other states, a few considerations need to be taken into account. Among others, the type of involvement should be determined or clarified. In order to effectively engage in participation in any operation, three operative terms in particular should be outlined or clarified: peacemaking, peacekeeping and peace enforcement - as clarity on these basic definitions have direct implications for South African involvement in peace support operations (Williams, 1995:90). Apart from clarifying the type(s) and nature of a peace mission, it is furthermore advisable that the following questions be addressed when considering a response to a request for engagement as they could be regarded as generic to all peace support operations:

- Are the circumstances so unacceptable to South Africa and its people that they demand action?

- Do political, diplomatic or economic actions/sanctions require military force?

- Will the resort to military force improve the situation?

- Can a credible coalition or multinational force be created? 
- What will be the desired end state (an event that determines the end of the crisis situation)?

The abovementioned questions boil down to a determination by the relevant decisionmakers as to whether direct involvement is necessary and if so, what type of influence should be used (Kearns, 1994:38).

As far as the positioning of the South African military is concerned, the Department of Defence has determined that participation in peace support operations will not be limited to the deployment of troops. It could also take the form of providing equipment; logistical support; humanitarian aid; engineering services; communication systems and medical personnel and facilities (Department of Defence, 1996:30). In addition, the Department has given consideration to certain types of peace support operations of which the following are regarded as relevant for future participation:

- Preventative diplomacy as an action taken in advance of a predicted crisis to prevent or limit violence. In particularly tense situations, preventative deployment of military forces may support such action.

- Peacemaking as a process of diplomacy, mediation, negotiation or other forms of peaceful settlement of conflict that seeks to end disputes and resolve the issues which gave rise to conflict. Military forces may be required to support the process.

- Peace-building as post-conflict action that strengthens and rebuilds civil infrastructures and institutions in order to provide a lasting peace. Military forces may assist in this process to restore civil authority, conducting elections, demobilising civil belligerents and controlling small arms.

- Peacekeeping as para-military operations undertaken with the consent of the disputant parties. Such operations aim to monitor and facilitate the implementation of an existing peace or truce agreement, and to support diplomatic efforts to reach a long-term settlement.

- Peace-enforcement as the application of threat of military force, pursuant to authorisation by the UN Security Council, to compel compliance with Security Council resolutions. It should accordingly be regarded as the application or threat of military force of which the aims are to maintain or restore peace and to support diplomatic efforts to reach a long-term settlement.

- Humanitarian or relief activities as the provision of humanitarian aid, disaster relief, health care and assistance to refugees and displaced persons in which military support may be required (Defence Review Drafting Team, 1997:31).

Aware of the necessity to determine criteria or guidelines for involvement in international peace support operations, the policy-makers in the Department of Defence have also proclaimed that South Africa will only become involved in specific peace initiatives if the following conditions are met:

- There must be parliamentary approval and public support. This requires an appreciation of the associated costs and risks, including the financial costs and the risk to 
military personnel.

- The operation should be authorised by the UN Security Council.

- Operations in Southern Africa should be sanctioned by the SADC and undertaken in conjunction with other SADC states. Similarly, operations in Africa should be sanctioned by the OAU.

- There should be realistic criteria for terminating the operation (Department of Defence, 1996:30).

- SANDF deployment must not be to the disadvantage of the country and must be feasible and sustainable in the face of competing national and departmental demands (Kritzinger, 1995:55).

The Department of Defence has furthermore proclaimed that the following issues should be addressed before committing SANDF forces to a peace operation:

- There must be a realistic appreciation of the extent of the SANDF's involvement in the light of its capabilities and other commitments.

- The following considerations must be taken into account with regard to the area of operations: the political risk to South Africa if it deploys forces in neighbouring countries; and the need for foreign assistance should forces be deployed beyond the operational reach of the SANDF.

Other cost-related considerations will entail the following:

- Channels of finance must be opened both with the UN and between the relevant South African government departments, and financial arrangements must be finalised in the contract.

- A time scale for the period of involvement must be established, and a disengagement plan for own troops must be in place.

- South African forces must be supported logistically from own resources for at least 28 weeks, after which UN support should be available (Defence Review Drafting Team, 1997:33-34).

As far as authority and determination of mandates are concerned, the following measures would apply:

- The UN Security Council would decide on the establishment of a peace operation and is responsible for extending or terminating the mission.

- A resolution of the Security Council would authorise the operation and determine the mandate.

- The overall direction would be in the hands of the Secretary-General who would act on behalf of, and report to, the Security Council.

- The Force Commander is responsible to the Secretary General for the efficient operation and administration of the multi-national peace force. He/she exercises operational control of the national forces of participating countries and national commanders are directly responsible and answerable to him/her (Defence Review Drafting Team, 1997:32). 


\section{OPERATIONAL CONSIDERATIONS FOR SOUTH AFRICAN ENGAGEMENT}

Many of the challenges facing the conduct of peace support operations are of a practical nature. These include, amongst others, the need for joint command-and-control arrangements and the formulation of clear rules of engagement, as well as SANDF preparations for participation in peace support operations.

\section{The need for joint command-and-control arrangements}

It needs to be noted that participating states in an international peace operation retain their autonomy and sovereignty. Such contending national priorities have the potential to translate themselves into problems of command-and-control, rules of engagement, disciplinary measures and personnel procedures. Differences of opinion in a volatile situation can potentially result in political differences and disagreement between the participating states (Williams, 1995:92).

Since the effectiveness of any military operation is inextricably tied to the quality of its command-and-control arrangements in-theater, all NATO member states have worked to establish NATO STANAGs (or memoranda of agreement covering joint tactics, operations and techniques). This has led to a "certain level of comfort" among NATO allies (Roos, 1993:14).

In any multinational peacekeeping effort it is thus advisable that the military planners working together should succeed in their attempts to standardise operational procedures. Being acutely aware of the challenges in this regard, the Department of Defence has accordingly recommended that the following issues be addressed before committing SANDF forces to a peace operation:

- Planning and execution of operations must be compatible with UN operating doctrines.

- A clear command-and-control system must be established and rules of engagement must be determined.

- Standardisation and compatibility must be established with other peacekeeping forces regarding drills; telecommunications; language; and doctrines and procedures for combined operations (Defence Review Drafting Team, 1997:33-34).

In order to prepare for peace missions, the SANDF is currently investigating the development of appropriate doctrines, operational procedures and training programmes in cooperation with foreign partners. South Africa has therefore recently entered into a number of international and regional defence agreements (Defence Review Drafting Team, 1997:33). 


\section{Formulating clear rules of engagement (ROE)}

ROE provide political direction, within legal parameters, and guidance to commanders at all levels governing the use of force. It provides the peacekeepers with a legal basis and assists them with firm legal authority. Moreover, it provides peacekeeping forces with international status and ground rules. At all times forces involved in peace support operations must operate in full compliance with the rules of the law of armed conflict. As such it furnishes principles of responsibility to guide the conduct of the peace mission (Cilliers, 1995:75).

During peace support operations most ROE are "conduct-based", that is, actions are based on a situation or threat that indicates a hostile act or intent. The threat may be a variety of groups or individuals but will not usually be an "enemy" in the "warfighting" sense (Joint Warfighting Center, 1995:82).

ROE have to be uniformly and strictly applied. An uneven application of ROE can potentially alienate the belligerents and may cause friction in relations between participating nations. All military personnel must know and understand ROE and it should therefore be simple and accessible in terms of content. As far as possible, personnel should be introduced to ROE prior to deployment (Williams, 1995:102).

From a South African viewpoint it is therefore of the utmost importance that its military functionaries working together with other nations or structures in the creation of multinational peace forces should succeed in determining ROE as this will be of particular relevance for the successful conduct of future peace support operations.

It should be mentioned that all personnel participating in Exercise Blue Hungwe (the Southern African multinational peace support exercise held early in 1997 in Zimbabwe) were issued with a blue card or pocket guide with a view to ensuring a clear understanding of the rules of engagement on the part of each and every person authorised to carry arms and ammunition. The blue card outlined certain general rules in relation to the conduct of the operation, rules to be followed before opening fire and rules applicable in case of opening fire against a person.

\section{SANDF preparations for participation in peace support operations}

The primary function of the SANDF is to defend South Africa against external military aggression. In terms of the current mandate of the SANDF, participation in peace support operations is a secondary function. Accordingly, South Africa shares the view with many of its neighbouring countries that the creation of a standing peacekeeping force is not required or feasible. The country is therefore likely to engage in peace support operations on an ad hoc basis if the need arises (Department of Defence, 1996:24;26).

As peace missions require a different mind-set than that required for warfighting, a train-up is desirable, if not imperative. Ideally a unit would have four to six weeks to 
prepare before engaging in a peacekeeping mission. The training package should be pretailored, with on-the-shelf lesson plans and examples of exercises and case studies to provide instruction down to all levels. Areas of training should ideally also include the nature of peacekeeping, regional orientations, negotiation skills, mine and booby trap training, checkpoint operations, investigating and reporting procedures, information collection, media interrelations and special joint staff training (Allen et al., 1993:60).

Being acutely aware of the practical challenges of peace support operations, the Department of Defence has indicated its intention to address the skills, attitudes and expectations of SANDF personnel through thorough training prior to deployment. It also intends to brief them on the political, cultural, linguistic and geographic features of the country of deployment, as well as to ensure their knowledge and understanding of ROE. It is also committed to combined training with forces of countries with which South Africa is likely to be involved in peace support operations (Defence Review Drafting Team, 1997:34-35).

Lastly, current policy also provides for participation in peace support operations in the short-term to be regarded with a fair measure of caution in the light of the fact that the integration of the former statutory and non-statutory forces is still underway (Department of Defence, 1996:30).

\section{CONCLUSION}

After years of isolation from the international community, South Africa is now a fullyfledged member of the community of nations. In the area of defence the country has entered into a number of international, regional and bilateral agreements while the South African military is preparing itself to fulfill a responsible role in international and regional peacekeeping.

Motivated by a combination of factors related to morality, altruism, national interests and international interest in African affairs, South Africa and its military intend to become involved in international and regional peace support operations sooner or later. In this regard the country is planning for its participation in the conduct of international peace missions on a multilateral basis through the $\mathrm{UN}$ and on the sub-continent through the $\mathrm{OAU}$ and the SADC.

Inevitable concomitant responsibilities flow from South Africa's position of economic and military strength. As the South African government is expected to serve as an African leader in international peacekeeping and especially in securing regional stability, it has to carefully consider any commitment to participation in this regard. Apart from clarifying parameters and criteria for involvement, the question of mandates, parameters of engagement, command-and-control arrangements, ROE and training for peacekeeping, among others, relate.

Being aware of the pitfalls of taking part in international and regional peace support operations, the Department of Defence regards any such participation with caution since 
the political and military dynamics of these operations are new to South Africa and its military. It has therefore rightfully proclaimed certain conditions to be met before becoming involved in such operations. It has also given consideration to the question of mandates, authority, decision-making and finances as these are decisive for the successful participation in peace support operations. The necessity for sound command-and-control arrangements, clear ROE and training for peace missions have likewise been realised, duly considered and accordingly addressed in the formulation of defence policy.

In order to prepare for peace support operations, the SANDF is furthermore investigating the development of appropriate doctrines, operational procedures and training programmes in co-operation with foreign partners. Most significant, however, is the new status enjoyed by South Africa in Southern Africa, and the current efforts to promote regional defence co-operation. Being strongly committed to a common security approach in Southern Africa, South Africa is now playing a pivotal role in shaping the security and defence policies within the region. As such, there seems to be a realisation that South Africa should carefully and systematically engage in participation in peacekeeping efforts if the country is to acquit itself in a responsible manner.

\section{BIBLIOGRAPHY}

Abizaid, J. P., "Lessons for Peacekeeping". Military Review, March 1993 : 11 - 19.

Allen, W.W., Johnson, D. and Nelson, J.T., "Peacekeeping and Peace Enforcement Operations". Military Review, October 1993: 53 - 61 .

Arnold, G., "The OAU and Peacekeeping in Africa". New African, January 1997: 33.

Berdal, M.R., "Whither UN Peacekeeping”. Adelpi Paper (281), October 1993 : 3 - 87.

Da Costa, P., "Keeping the Peace". Africa Report, May - June 1995: 26 - 29.

Defence Review Drafting Team. See South Africa, Defence Review: First Report on Defence Posture, Functions and Foreign Design, 1997.

Department of Defence. See South Africa, White Paper on Defence, 1996.

Cilliers, J., SANDF Participation in UN Peace Support Operations. (In Cilliers, J. and Mills, G. (eds.), Peacekeeping in Africa. Halfway House, Institute for Defence Policy and South African Institute of International Affairs, $1995: 57$ - 88.)

Cilliers, J. and Malan, M., "From Destabilisation to Peace-keeping in Southern Africa: The Potential Role of South Africa". Africa Insight 26(4), 1996 : 339 - 346.

Gutteridge, W., "South Africa's Future Defence and Security: Identifying the National Interest". Conflict Studies (298), April 1997 : 1 - 24.

Joint Warfighting Center. Joint Task Force Commander's Handbook for Peace Operations. Monroe, Department of the Army, 1995. 
Kearns, D.L., "The Need for Criteria in UN Peace Operations". Military Review, July 1994 : 34 - 42. Kritzinger, W.G., SANDF Participation in UN Peace Support Operations. (In Shaw, M. and Cilliers, J. (eds.), South Africa and Peacekeeping in Africa. Halfway House, Institute for Defence Policy, 1995 : 51 - 59.)

Maloney, S.M., "Insights into Canadian Peacekeeping Doctrine”. Military Review, March - April $1996: 12-23$.

Nhara, W., The OAU and the potential role of regional and sub-regional organisations. (In Cilliers, J. and Mills, G. (eds.), Peacekeeping in Africa. Halfway House, Institute for Defence Policy and South African Institute of International Affairs, 1995 : 99 - 108.)

Nöffke, C., "Africa's Role in International Peacekeeping Operations: With Emphasis on Africa's Peacekeeping Co-operation Priorities". African Armed Forces Journal, April 1995 : 14 -17.

NORDSAMFN (Joint Nordic Committee for UN Military Matters). Nordic UN Stand-by Forces. Tryckericentralen Ab, Helsingfors, 1993.

Pahad, A., South Africa and Preventative Diplomacy. (In Cilliers, J. and Mills, G. (eds.), Peacekeeping in Africa. Halfway House, South African Institute for Defence Policy and Institute for International Affairs, 1995 : 153 - 165.)

Ramsbotham, D., "The Changing Nature of Intervention: The Role of UN Peacekeeping". Conflict Studies (282), August 1995 : 1 - 23.

Rifkind, M., "Peacekeeping or Peacemaking? Implications and Prospects". The Rusi Journal, April $1993: 1-6$.

Roos, J.G., "The Perils of Peacekeeping”. Armed Forces Journal, December 1993 : 13 - 17.

Shaw, A., “African Peacekeepers in Training”. The Citizen, 26 May 1997 : 6.

South Africa, Defence Review Drafting Team. Defence Review: First Report on Defence Posture, Functions and Foreign Design. Unpublished, 1997.

South Africa, Department of Defence. White Paper on Defence (as approved by Parliament on 14 May 1996). Cape Town, SAN Publications Unit, 1996.

Williams, R., "Peace Operations and the South African Armed Forces". Strategic Review for Southern Africa XVII(2), November $1995: 87$ - 107.

Williams, R., "Don't Hold the African Crisis Response Force Hostage to Unrealistic Demands". ISS Papers (20), April $1997: 1$ - 3. 